\title{
ELECTROCARDIOGRAPHIC MANIFESTATIONS IN ACUTE METHANOL POISONING CANNOT PREDICT MORTALITY*
}

\author{
Hossein SANAEI-ZADEH ${ }^{1}$, Mohammadali EMAMHADI ${ }^{2}$, Hoorvash FARAJIDANA ${ }^{3}$, \\ Nasim ZAMANI ${ }^{4}$, and Abdollah AMIRFARHANGI ${ }^{5}$ \\ Emergency Room/Division of Medical Toxicology, Hazrat Ali-Asghar (p) Hospital, Shiraz University of Medical \\ Sciences, Shiraz ${ }^{1}$, Department of Forensic Medicine and Toxicology, Shahid Beheshti University of Medical Sciences, \\ Tehran', Shahid Madani Hospital, Alborz University of Medical Sciences, Karaj ${ }^{3}$, Department of Clinical Toxicology, \\ Loghman Hakim Hospital, Shahid Beheshti University of Medical Sciences, Tehran ${ }^{4}$, Department of Cardiology, \\ Hazrat Rasoul Akram (p) Hospital, Iran University of Medical Sciences, Tehran ${ }^{5}$, Iran
}

Received in June 2012

CrossChecked in September 2012

Accepted in February 2013

\begin{abstract}
The aim of this retrospective observational case series was to determine electrocardiographic (ECG) manifestations in patients poisoned with methanol and see whether they could predict mortality. We also wanted to see whether there was an association between ECG changes and time elapsed between ingestion and treatment, age, sex, seizure, coma (Glasgow Coma Scale $\leq 8$ ), arterial blood gas (ABG) parameters, and serum potassium levels on hospital admission. The study included 42 patients aged $31.14 \pm 12.5$ years. Twenty-five survived and 17 died. Almost all patients had one or more abnormal ECG findings, including heart rate, rhythm, and conduction abnormalities. However, we found no significant difference between survivors and non-survivors. QTc interval did not correlate with time elapsed between ingestion and treatment, age, sex, seizure and coma, $\mathrm{HCO}_{3}^{-}$, or serum potassium level. Similarly, T waves showed no correlation with serum potassium. ECG abnormalities did not correlate with coma or seizure. Even though cardiotoxicity in methanol poisoning is high, none of the ECG abnormalities found in our study predicted mortality. This however does not rule out the need to routinely run ECG for cardiotoxicity in every single patient poisoned by methanol.
\end{abstract}

KEY WORDS: death, ECG, electrocardiogram, intoxication, methanol

Formate is a toxic metabolite of methanol that causes acidosis and inhibits cell cytochromes (1-3). The clinical picture of acute methanol poisoning includes gastrointestinal, visual, and nervous system signs and symptoms such as headache, dizziness, nausea, vomiting, abdominal pain, visual disturbances, coma, respiratory arrest, seizure, blindness,

\footnotetext{
* This article has partly been presented at the 11th Scientific Congress of Asia Pacific Association of Medical Toxicology held in Hong Kong from 29 November to 1 December 2012.
}

gastrointestinal haemorrhage, putaminal haemorrhage and infarction, and pancreatitis (1, 4-12). Diagnosis is based on these clinical signs and symptoms, acidbase status, direct serum methanol levels and/or serum formate, and anion and osmolal gaps (4). Clinical guidelines for methanol poisoning management recommend using an antidote (ethanol or fomepizole), intravenous (IV) sodium bicarbonate, folic or folinic acid, and often haemodialysis $(1,2,13)$. This poisoning can be intentional and unintentional, isolated and epidemic $(7,11,12,14-17)$. In Iran, alcohol 
consumption is banned and methanol poisoning is usually associated with illegal consumption of methanol mixed with other alcohols, including smuggled alcohol, homemade liquor, pharmaceutical ethanol preparations, or industrial alcohol (containing a mixture of varying percentages of ethanol and methanol with colour additives) $(12,18-20)$. To date, several studies have been performed to identify the prognostic factors of mortality in methanol poisoning $(5,7,11,14-16,18,20,21)$. To the best of our knowledge, no literature has considered electrocardiographic (ECG) abnormalities as potential mortality predictors. Articles that do report ECG changes in patients poisoned with methanol are inconsistent $(7,22-26)$. In addition, little is known about the relationship between ECG parameters and metabolic/electrolyte disturbances as well as the signs and symptoms of methanol poisoning.

Our aim was therefore to see if patients who had died from methanol poisoning differed in ECG parameters from those who had survived, hoping to identify parameters that might predict mortality. We also wanted to see whether ECG changes were associated with time elapsed between ingestion and treatment, age, sex, seizure, coma, arterial blood gas (ABG) parameters, and serum potassium levels.

\section{METHODS}

In this observational retrospective case series we reviewed hospital records of all patients who had been diagnosed and treated for methanol poisoning in three Tehran hospitals [Loghman Hakim, Shohada Yaftabad, and Hazrat Rasoul Akram (p)] from March 2003 to March 2011. The study also included patient data available from two studies published earlier $(12,20)$.

Methanol poisoning was diagnosed by admitting physicians, based on a history of alcohol consumption (homemade, smuggled, industrial), clinical manifestations, laboratory findings, metabolic acidosis with an elevated anion gap, and computed tomography (CT) of the brain $(12,20)$. The charts were then reevaluated by the authors. Inter-rater reliability to determine agreement between evaluators (authors) was tested using kappa statistic (27). Any discrepancies between evaluators were resolved by reviewing the original chart. The study included patients with confirmed diagnosis of methanol poisoning whose first 12-lead ECG was performed on hospital admission. Patients with the history of underlying heart or lung disease were excluded from the study.
All included patients had received therapy with ethanol, sodium bicarbonate, folic or folinic acid, and haemodialysis, as indicated (28). None received fomepizole, as it is not available in Iran.

We used patient charts to extract information about age, sex, time between alcohol consumption and hospital admission, coma (Glasgow Coma Scale $\leq 8$ ) and seizure on admission, $\mathrm{ABG}$ tests before treatment, and serum potassium levels. This information was recorded in standardised abstraction forms (29).

We proceeded by evaluating the first 12-lead ECG performed on hospital admission and by recording the following ECG parameters: heart rate, PR interval, QRS interval, QRS frontal plane axis, and corrected QT interval (QTc) [based on the Bazett's formula (30)]. Findings such as right or left axis deviation, right or left bundle branch block (RBBB or LBBB), ST-T changes, early repolarisation, premature ventricular contractions, premature atrial contractions, atrial fibrillation, right or left atrial enlargement, right or left ventricular strain pattern, and ventricular dysrhythmias including type were also recorded according to procedures described elsewhere $(31,32)$. Interpretation of the ECGs was supervised by two cardiologists blind to the topic of the study.

We used the Statistical Package for Social Sciences software (version 17, SPSS Inc., Chicago, IL, USA) for descriptive statistics, Kolmogorov-Smirnov test, Mann-Whitney U test, Student's $t$-test, Pearson chisquare or Fisher's exact test, and Pearson correlation coefficient (r). In addition, we ran kappa $(K)$ statistic (27) to determine the consistency of the evaluation of the ECGs between the cardiologists. A $P$ value of less than 0.05 was considered statistically significant. Our study was approved by the regional ethics committee.

\section{RESULTS}

After we agreed on the diagnosis of methanol poisoning $(K=1.00, P<0.001)$, a total of 42 patients met the inclusion criteria. Of them, 36 were men and six women. The mean patient age was $(31.14 \pm 12.5)$ years; range: (16 to 75$)$ years. Twenty-five patients survived the poisoning and 17 died.

Table 1 compares the admission data between survivors and non-survivors, including ECG parameters. ECG heart rate above 100 beats per minute was found in 18 patients, $\mathrm{PR}$ interval $>200 \mathrm{~ms}$ in one, QRS interval $\geq 120 \mathrm{~ms}$ in one, prolonged QTc interval $(\geq 450 \mathrm{~ms}$ for men and $\geq 460 \mathrm{~ms}$ for women) (33) in 25 , atrial 
fibrillation in two, flat T waves in leads I and/or II in six, right atrial enlargement in one, right ventricular strain pattern in 10, left atrial enlargement in two, and left ventricular strain pattern in three patients. Three patients had concomitant right and left ventricular strain patterns (Figure 1). In addition, we recorded right axis deviation of more than $110^{\circ}$ in one patient, RBBB in two, early repolarisation in four, premature ventricular contractions in three, premature atrial contractions in one, and ST depression in leads II, III, and aVF (pointing to inferior ischaemia) in one patient. None of the patients had ventricular dysrhythmias. The $K$ for inter-rater reliability analysis of ECG interpretation between the cardiologists was 0.84 (95\% confidence interval; range: 0.67 to 1.00$)$ at $P<0.001$.

No significant differences in ECG parameters and ECG abnormalities were found between the survivors and non-survivors. Furthermore, ECG abnormalities did not correlate with coma or seizure. However, we established a weak correlations between QTc interval and $\mathrm{pH}(\mathrm{r}=-0.353, P=0.023)$ or base deficit $(\mathrm{BD}$; $\mathrm{r}=0.387, P=0.016)$. QTc interval however did not correlate with time elapsed between methanol consumption and treatment, age, sex, seizure or coma,
$\mathrm{HCO}_{3}^{-}$, or serum potassium. The same is true for ECGs with or without flat $\mathrm{T}$ waves and serum potassium (Table 1).

\section{DISCUSSION}

Our results show that a large majority of patients poisoned with methanol, 35 of them, had ECG abnormalities on admission to hospital. However, none of the abnormalities turned out to be an independent predictor of mortality.

Our findings differ from earlier reports in some of the abnormalities. Hazra et al. (24), for instance, detected right ventricular strain pattern in all 11 methanol-poisoned patients with ECG records. They also found right atrial enlargement in all patients except one. These findings led them to conclude that methanol specifically affected the right heart. We, in turn, observed left ventricular strain in three patients, concomitant right and left ventricular strain in three patients and right ventricular strain in only 10 patients. In other words, our findings suggest that methanol-

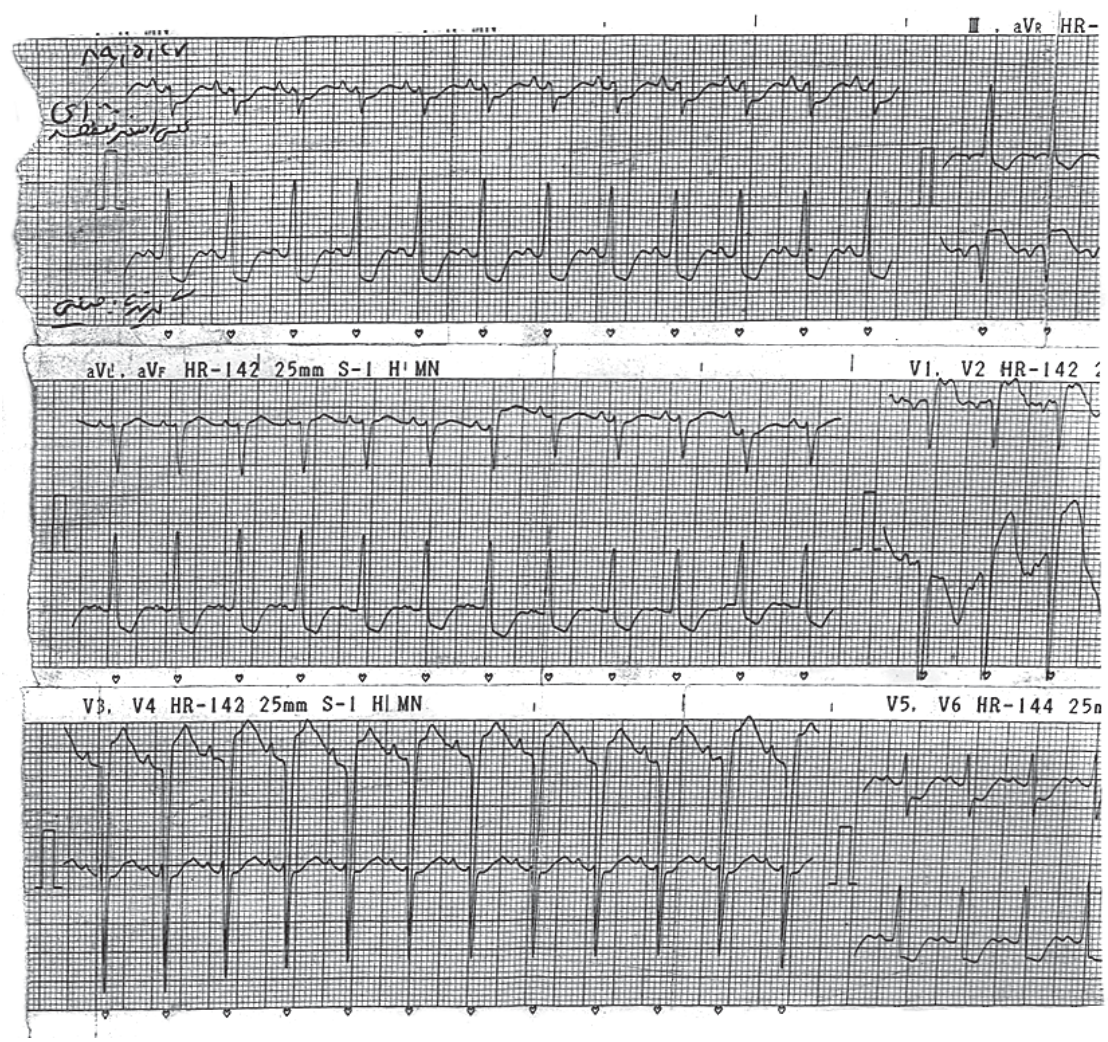

Figure 1 Electrocardiogram of one of the patients with concomitant right and left ventricular strain pattern $(31,32)$ 
Table 1 Electrocardiographic parameters and distribution of age, sex, time between ingestion and treatment, coma, seizure, $\mathrm{pH}, \mathrm{pCO}_{2}, \mathrm{HCO}_{3}^{-}, \mathrm{BD}$, and serum potassium level on admission to hospital

\begin{tabular}{|c|c|c|c|c|}
\hline & All & Survivors & Non-survivors & $\begin{array}{c}P \text {-value (applied } \\
\text { statistical test) }\end{array}$ \\
\hline Patients / number & 42 & 25 & 17 & \\
\hline Age / years & $31.14( \pm 12.5)^{\mathrm{a}}$ & $30( \pm 14)$ & $33( \pm 11)$ & 0.137 (MWU) $^{b}$ \\
\hline Sex (male/female) & $36 / 6$ & $20 / 5$ & $16 / 1$ & 0.374 (Fisher's exact test) $^{b}$ \\
\hline $\begin{array}{l}\text { Time interval between } \\
\text { ingestion and treatment / } \mathrm{h}\end{array}$ & $41.76( \pm 23.82)$ & $48.63( \pm 26.67)$ & $32.43( \pm 15.77)$ & $0.070(\mathrm{MWU})^{\mathrm{b}}$ \\
\hline Coma $(\mathrm{GCS} \leq 8) /$ number & 18 & 4 & 14 & $<0.001$ (Fisher's exact test) \\
\hline Seizure & 7 & 0 & 7 & 0.001 (Fisher's exact test) \\
\hline $\mathrm{pH}$ & $7.02( \pm 0.30)$ & $7.16( \pm 0.25)$ & $6.80( \pm 0.24)$ & $<0.001$ (Student t test) \\
\hline $\mathrm{pCO}_{2} / \mathrm{mm} \mathrm{Hg}$ & $33.23( \pm 17.57)$ & $26.24( \pm 10.81)$ & $44.16( \pm 20.67)$ & 0.001 (Student $t$ test) \\
\hline $\mathrm{HCO}_{3}^{-} / \mathrm{mmol} \mathrm{L}^{-1}$ & $8.45( \pm 5.94)$ & $10.33( \pm 6.40)$ & $5.33( \pm 3.40)$ & 0.008 (Student $t$ test) \\
\hline $\mathrm{BD} / \mathrm{mmol} \mathrm{L}^{-1}$ & $22.35( \pm 12.27)$ & $17.20( \pm 11.44)$ & $31.18( \pm 8.02)$ & $<0.001$ (Student $\mathrm{t}$ test) \\
\hline $\begin{array}{l}\text { Serum potassium level / } \\
\mathrm{mEq} \mathrm{L}^{-1}\end{array}$ & $4.6( \pm 1.3)$ & $4.5( \pm 1.1)$ & $4.7( \pm 1.5)$ & $0.932(\mathrm{MWU})^{\mathrm{b}}$ \\
\hline Rate / beats per min & $95( \pm 20)$ & $93( \pm 20)$ & $98( \pm 19)$ & 0.589 (MWU) $^{\mathrm{b}}$ \\
\hline PR interval / ms & $168( \pm 28)$ & $169( \pm 29)$ & $163( \pm 28)$ & $0.571(\mathrm{MWU})^{\mathrm{b}}$ \\
\hline $\begin{array}{l}\text { Maximal limb-lead QRS } \\
\text { interval / ms }\end{array}$ & $87( \pm 28)$ & $86( \pm 31)$ & $88( \pm 23)$ & $0.686(\mathrm{MWU})^{\mathrm{b}}$ \\
\hline QTc interval / ms & $467( \pm 49)$ & $465( \pm 33)$ & $470( \pm 67)$ & $0.367(\mathrm{MWU})^{\mathrm{b}}$ \\
\hline QRS frontal plane axis $\left(^{\circ}\right)$ & $+50( \pm 44)$ & $+55( \pm 39)$ & $+43( \pm 53)$ & $0.644(\mathrm{MWU})^{\mathrm{b}}$ \\
\hline
\end{tabular}

MWU: Mann-Whitney U test; BD: base deficit; GCS: Glasgow Coma Scale

${ }^{a}$ Data are presented as mean value $( \pm S D)$.

${ }^{b}$ Not significant.

induced cardiotoxicity is not exclusive to the right heart as Hazra et al. seem to suggest.

Weisberger and MacLaughlin (25) reported that the most frequent ECG finding in eight patients poisoned with methanol were low-voltage $T$ waves in leads I and II. They also showed prolonged QTc in four patients. In contrast to Weisberger and MacLaughlin, QTc in our study was prolonged in 25 patients and only 6 had flat T waves in leads I and/or II.

Our study has shown that QTc interval not only bears little relation with $\mathrm{pH}$ and $\mathrm{BD}$, but also has no association with $\mathrm{HCO}_{3}^{-}$. Our statistical analysis also shows that QTc prolongation does not correlate with sex and age nor do QTc prolongation and flat $\mathrm{T}$ waves correlate with potassium levels.

Koivusalo (34) suggests that cardiac tissue metabolises methanol in vitro. Therefore, it is reasonable to assume that in patients with acute methanol poisoning, it is methanol metabolised to formic acid that depresses the myocardium and not acidosis as we did not find a statistically significant relationship between acidosis and ECG abnormalities.
Opherk et al. (35) have shown that some ECG changes may occur in the postictal phase of seizures. All seven of our non-survivors had seizures, but their ECG abnormalities did not correlate with seizures. This suggests that ECG changes are related to methanol poisoning and not to seizure.

There are some limitations to our study; confirmatory methanol and formate levels were not available for all patients, but the diagnosis based on other information and clinical findings $(K=1.00$, $P<0.001)$ is reliable.

As we did not look into the relationship between serum calcium and magnesium and ECG abnormalities, future studies will need to address this question.

To conclude, even though cardiotoxicity in methanol poisoning is high, ECG abnormalities can not predict mortality. However, from the clinical point of view, we suggest that ECG should become a routine procedure in methanol poisoning to monitor for cardiotoxicity.

\section{Acknowledgment}

The authors wish to thank Dr Rahbar and Dr Sezavar, cardiologists in the Cardiology Department 
of Hazrat Rasoul Akram (p) Hospital, Tehran, Iran, for their kind cooperation in supervising the interpretation of the ECGs.

\section{Conflict of Interest}

The authors declare no conflict of interest in this study.

\section{REFERENCES}

1. Barceloux DG, Bond GR, Krenzelok EP, Cooper H, Vale JA; American Academy of Clinical Toxicology Ad Hoc Committee on the Treatment Guidelines for Methanol Poisoning. American Academy of Clinical Toxicology practice guidelines on the treatment of methanol poisoning. J Toxicol Clin Toxicol 2002;40:415-46.

2. Jacobsen D, McMartin KE. Methanol and ethylene glycol poisonings. Mechanism of toxicity, clinical course, diagnosis and treatment. Med Toxicol 1986;1:309-34.

3. Nicholls P. The effect of formate on cytochrome aa3 and on electron transport in the intact respiratory chain. Biochim Biophys Acta 1976;430:13-29.

4. Hovda KE, Hunderi OH, Rudberg N, Froyshov S, Jacobsen D. Anion and osmolal gaps in the diagnosis of methanol poisoning: clinical study in 28 patients. Intensive Care Med 2004;30:1842-6. doi: 10.1007/s00134-004-2373-7

5. Hovda KE, Hunderi OH, Tafjord AB, Dunlop O, Rudberg N, Jacobsen D. Methanol outbreak in Norway 2002-2004: epidemiology, clinical features and prognostic signs. J Intern Med 2005;258:181-90. doi: 10.1111/j.1365-2796.2005.01521.x

6. Teo SK, Lo KL, Tey BH. Mass methanol poisoning: a clinicobiochemical analysis of 10 cases. Singapore Med J 1996;37:485-7.

7. Bennet IL Jr, Cary FH, Mitchell GL Jr, Cooper MN. Acute methyl alcohol poisoning: a review based on experiences in an outbreak of 323 cases. Medicine 1953;32:431-63.

8. Sefidbakht S, Rasekhi AR, Kamali K, Borhani Haghighi A, Salooti A, Meshksar A, Abbasi HR, Moghadami M, Nabavizadeh SA. Methanol poisoning: acute MR and CT findings in nine patients. Neuroradiology 2007;49:427-35. doi: $10.1007 / \mathrm{s} 00234-007-0210-8$

9. Sanaei-Zadeh H. Typical bilateral putaminal lesions of methanol intoxication. J Emerg Med 2012;42:178-9. doi: 10.1016/j.jemermed.2009.08.010

10. Hantson P, Mahieu P. Pancreatic injury following acute methanol poisoning. J Toxicol Clin Toxicol 2000;38:297303.

11. Naraqi S, Dethlefs RF, Slobodniuk RA, Sairere JS. An outbreak of acute methyl alcohol intoxication. Aust N Z J Med 1979;9:65-98.

12. Sanaei-Zadeh H, Zamani N, Shadnia S. Outcomes of visual disturbances after methanol poisoning. Clin Toxicol (Phila) 2011;49:102-7. doi: 10.3109/15563650.2011.556642

13. Hovda KE, Jacobsen D. Expert opinion: fomepizole may ameliorate the need for hemodialysis in methanol poisoning.
Hum Exp Toxicol 2008;27:539-46. doi: 10.1177/0960327108095992

14. Mathieu P, Hassoun A, Lauwerys R. Predictors of methanol intoxication with unfavourable outcome. Hum Toxicol 1989;8:135-7.

15. Liu JJ, Daya MR, Carrasquillo O, Kales SN. Prognostic factors in patients with methanol poisoning. J Toxicol Clin Toxicol 1998;36:175-81.

16. Paasma R, Hovda KE, Tikkerberi A, Jacobsen D. Methanol mass poisoning in Estonia: outbreak in 154 patients. Clin Toxicol (Phila) 2007;45:152-7. doi: 10.1080/15563650600 956329

17. Meyer RJ, Beard ME, Ardagh MW, Henderson S. Methanol poisoning. N Z Med J 2000;113:11-3.

18. Hassanian-Moghaddam H, Pajoumand A, Dadgar SM, Shadnia Sh. Prognostic factors in methanol poisoning. Hum Exp Toxicol 2007;26:583-6.

19. Massoumi G, Saberi K, Eizadi-Mood N, Shamsi M, Alavi M, Morteza A. Methanol poisoning in Iran, from 2000 to 2009. Drug Chem Toxicol 2012;35:330-3. doi: 10.3109/014 80545.2011.619193

20. Sanaei-Zadeh H, Esfeh SK, Zamani N, Jamshidi F, Shadnia $\mathrm{S}$. Hyperglycemia is a strong prognostic factor of lethality in methanol poisoning. J Med Toxicol 2011;7:189-94. doi: 10.1007/s13181-011-0142-x

21. Coulter CV, Farquhar SE, McSherry CM, Isbister GK, Duffull SB. Methanol and ethylene glycol acute poisoningspredictors of mortality. Clin Toxicol (Phila) 2011;49:900-6. doi: 10.3109/15563650.2011.630320

22. Rakus A, Kroczak M, Ruszkowski P. Methanol poisoning case report. Przegl Lek 2005;62:514-6.

23. Roe O. Methanol poisoning: Its clinical course, pathogenesis, and treatment. Acta Med Scand 1946;126 (Suppl 182):1253.

24. Hazra DK, Seth HC, Mathur KS, Wahal PK, Prakash V, Maheshwari BB, Tandan S. Electrocardiographic changes in acute methanol poisoning. J Assoc Physicians India 1974;22:409-13.

25. Weisberger AS, MacLaughlin JA. Electrocardiographic changes associated with methyl alcohol poisoning. Am Heart J 1947;33:27-33. doi: 10.1016/0002-8703 (47)90422-5

26. Cavalli A, Volpi A, Maggioni AP, Tusa M, De Pieri G. Severe reversible cardiac failure associated with methanol intoxication. Postgrad Med J 1987;63:867-8. doi:10.1136/ pgmj.63.744.867

27. Landis JR, Koch GG. The measurement of observer agreement for categorical data. Biometrics 1997;33:15974.

28. Jacobsen D, Hovda KE. Methanol. In: Shannon MW, Borron SW, Burns MJ, editors. Haddad and Winchester's clinical management of poisoning and drug overdose. $4^{\text {th }}$ ed. Philadelphia (PA): Saunders, Elsevier; 2007. p. 605-11.

29. Gilbert EH, Lowenstein SR, Koziol-McLain J, Barta DC, Steiner J. Chart reviews in emergency medicine research: Where are the methods? Ann Emerg Med 1996;27:305-8.

30. Bazett H. An analysis of the time-relations of electrocardiograms. Heart 1920;7:353-70.

31. Harrigan RA, Jones K. ABC of clinical electrocardiography. Conditions affecting the right side of the heart. BMJ 2002;324:1201-4. doi: 10.1136/bmj.324.7347

32. Edhouse J, Thakur RK, Khalil JM. ABC of clinical electrocardiography. Conditions affecting the left side of the 
heart. BMJ 2002;324:1264-7. doi:10.1136 bmj.324.7348.1264

33. Rautaharju PM, Surawicz B, Gettes LS. AHA/ACCF/HRS recommendations for the standardization and interpretation of the electrocardiogram. Part IV: the ST segment, T and U waves, and the QT interval. JACC Cardiovasc Imaging 2009;53:982-91.
34. Koivusalo M. Studies on the metabolism of methanol and formaldehyde in the animal organism. Acta Physiol Scand 1956;39 (Suppl 131):1-103.

35. Opherk C, Coromilas J, Hirsch LJ. Heart rate and EKG changes in 102 seizures: analysis of influencing factors. Epilepsy Res 2002;52:117-27. 


\section{Sažetak}

\section{ELEKTROKARDIOGRAFSKE MANIFESTACIJE KOD AKUTNOG TROVANJA METANOLOM NE MOGU PREDVIDJETI SMRTNOST}

Cilj je ovog retrospektivnoga opservacijskog istraživanja bio utvrditi elektrokardiografske (EKG) manifestacije u bolesnika otrovanih metanolom te vidjeti mogu li one poslužiti kao pretkazatelji smrtnosti. Također smo željeli utvrditi postoji li povezanost između promjena na EKG-u i vremena proteklog od unosa metanola do liječenja, zatim dobi, spola, epileptičkog napadaja, kome ( $\leq 8$ prema ljestvici Glasgow), nalaza plinske analize arterijske krvni te razina kalija u serumu u trenutku hospitalizacije. Ispitivanje je obuhvatilo 42 bolesnika u dobi od 31.14 \pm 12.5 godine. Dvadeset i petero je preživjelo trovanje, a 17-ero umrlo. Gotovo su svi bolesnici imali jedan abnormalni EKG parametar ili više njih među kojima brzinu otkucaja srca, srčani ritam i provodljivost. Nismo međutim našli značajnih razlika između preživjelih i umrlih. QTc interval nije korelirao s vremenom proteklim od unosa metanola do liječenja, s dobi, spolom, epileptičkim napadajem, komom, $\mathrm{HCO}^{3-}$ odnosno razinama kalija u serumu. Isto tako, $\mathrm{T}$ valovi nisu korelirali s kalijem u serumu. Abnormalni EKG nalazi nisu korelirali s komom i epileptičkim napadajima. Premda je kardiotoksičnost značajna kod trovanja metanolom, nijedan abnormalni EKG nalaz nije mogao predvidjeti smrtnost. To međutim ne isključuje potrebu za rutinskim EKG pregledima radi otkrivanja kardiotoksičnosti u svih bolesnika otrovanih metanolom.

KLJUČNE RIJEČI: EKG, elektrokardiogram, metanol, trovanje, smrt

\section{CORRESPONDING AUTHOR:}

Hossein Sanaei-Zadeh, MD, Associate Professor of Forensic Medicine and Clinical Toxicology Medical School, Shiraz University of Medical Sciences Emergency Room/Division of Medical Toxicology Hazrat Ali-Asghar (p) Hospital Meshkinfam Street, 7143918796 Shiraz, Iran Email:h-sanaiezadeh@tums.ac.ir 